\title{
3D Linear FE-Analysis of Unreinforced Masonry House Under Static Earthquake Load
}

\author{
Taufiq Ilham Maulana ${ }^{1 *}$, Melati Sukma Astie Baroo ${ }^{1}$ \\ ${ }^{I}$ Department of Civil Engineering, Universitas Muhammadiyah Yogyakarta, Indonesia \\ *Corresponding author. Email: taufiq.im@ft.umy.ac.id
}

\begin{abstract}
The world population has risen significantly in the last several decades, and this phenomenon creates a challenge to provide affordable housing for the family. Indonesia, the fourth largest populated country in the world, recently has a well-known national program regarding this issue, namely one million housing for its people. The house is commonly built with a simple structure, mainly constructed with masonry bricks, and it comes with very typical area size options. However, this country has various kinds of natural disasters, including earthquakes. Thus, the buildings must be resilient under those hazards. This paper aims to study typical unreinforced masonry houses in Indonesia, especially under earthquake load. The analysis was performed using the finite element method by implementing the Von-Mises failure criterion. Four area types of building: 21, 36, 45, and 50 square meters were modelled three-dimensionally. The load was given horizontally and statically based on the current national valid provision. Stress distributions and displacement were inspected. Moreover, the material strength was based on previous research and created homogeneously. The result revealed that the displacement was still below the initiated limit. However, several specimens have exceeded maximum set stress, especially near the perpendicular plane area.
\end{abstract}

Keywords-3D linear analysis, finite element method, static earthquake load, typical masonry house, homogeneous model

\section{INTRODUCTION}

According to the United Nations report, the world's human population continues to increase until it is estimated to have reached 7.7 billion by mid-2019 [1]. This rising number of the human population derives challenges in providing adequate housing. In 2014, Indonesia had a national program to solve these problems by providing one million ready-to-live houses for its citizens. The residences are commonly built from masonry and mostly reinforced with any structures such as reinforced concrete frames.

The types and forms of houses available and marketed in Indonesia are very diverse. However, these houses can be identified with one thing in common, building area size. This building area is often made typically according to the number of rooms and facilities available in the house. The brick wall serves as a majority structure as well as a barrier between spaces.

On the other hand, Indonesia is a country with several natural disasters, one of which is an earthquake. Indonesia has a long history of tectonic earthquake activity for being located in a prone area and is traversed by the Ring of Fire. If not planned and built with good quality, material damage and casualties can occur due to earthquakes.

Indonesia recently issues the newest Earthquake Hazard Map in 2019 [2] containing design parameters for determining the magnitude of earthquake loads to be considered in building design. This map update has been carried out since 2002, 2010, 2012, and 2017, which considers and mainly adjusts to the possibility of additional earthquake magnitude changes due to the discovery of new faults. With the update provided in the new provision, the existing masonry houses must be rechecked, and there is a possibility that it will become more vulnerable and need attention from all related stakeholders, especially the owners and users of the building.

Masonry has been widely studied for its physical properties. Prayuda et al., in 2018, studied the physical properties of red bricks in Yogyakarta, Indonesia [3]. The research uncovered that several brick samples had not met the requirements, especially from compressive strength. Thereby, the masonry usage requires caution. Similar to Prayuda, Narayanan and Sirajuddin in 2013 also observed the physical properties of bricks, but the locations examined cover a wider area, and these data are used for further research on numerical modeling [4]. In addition to research on its physical properties, the analysis of reinforced concrete frame structures using bricks has also been carried out by Maidiawati et al. in 2017 [5]. This study presents a brick wall affecting the lateral resistance of a structure. This study result revealed that the brick between reinforced concrete frame structures would increase the lateral resistance, even though the collapse began from the masonry. 
In previous studies, several simple houses constructed from unreinforced masonry were chosen and modeled as simplification form to 3-dimensional models where the samples were inspected under lateral loads. For example, Milani et al. in 2007 conducted a study on the limit analysis of brick buildings against horizontal loads [6]. In general, the horizontal load is representative of seismic loading on a structure. This study developed a micro-mechanical model for masonry wall structures in-plane and out-of-plane by applying kinematic theory to the limit analysis. Validation has also been carried out and demonstrated. Moreover, Vamvatsikos and Pantzopulou in 2016 also tried to simplify the mechanical model to estimate the vulnerability of unreinforced masonry building to seismic, especially for historical buildings, by proposing a preliminary analysis method using a representative of the single degree of freedom (SDOF) and estimating the vibration mode in both main directions [7].

From several papers above, it is known that the analysis of masonry buildings is not easy to perform due to many obstacles such as the inhomogeneity of the material, the interactions between various structural elements, and generally having a complex plan. However, in this paper, famous simple masonry buildings in Indonesia were modeled using the three-dimension finite element method. Several limitations were taken, such as defining low strength and homogeneous materials and types of analysis that are still within linear limits. The analysis of the finite element method was used by Maulana in 2018 to measure stress and deformation in a structure [8-9]. With all the simplifications taken in this study, the earthquake loading on simple buildings for several types of houses with the same area, the displacement and stress analysis are presented. Through this research, it is expected that the vulnerability of unreinforced masonry buildings can be displayed to stakeholders and become a reference for future research.

\section{RESEARCH METHOD}

\subsection{General}

Four simple masonry houses with typical building area sizes were selected and modeled in three dimensions and analyzed using the finite element method. The selected area types were $21 \mathrm{~m}^{2}, 36 \mathrm{~m}^{2}, 45 \mathrm{~m}^{2}$, and $50 \mathrm{~m}^{2}$, with the same structure height of $3.4 \mathrm{~m}$, where the type of building area observed by the author was a house type widely available and offered in the Indonesian markets. The observation included two parameters, checking the response displacement and stress when given a lateral load representing the earthquake load. The application of earthquake loading to buildings was carried out by implementing the equivalent static and time history [10]. In this study, the earthquake load was given statically and calculated according to the structure's weight and adjusted to the equivalent static method referring to SNI 1726:2019, taken from a case study located in Padang, Indonesia. This location arguably generates a large enough earthquake load, thus representing Indonesia in general, with spectral value at 0.2 second period (SDS) of $1.94 \mathrm{~g}$ and spectral value at 1 second period (SD1) of $1.14 \mathrm{~g}$, considering the assumed natural period of the building structure of 0.12 seconds and the value of the modification factor $\mathrm{R}$ was 1.5 . The applied lateral static load was also carried out in two different main directions, the $\mathrm{X}$-axis and the $\mathrm{Y}$-axis. For each axis, the lateral static load was conducted with two variations, in the outside of the plane wall called the direction A and C, or parallel to the roof side illustrated as directions B and D. The type of loading direction is presented in Fig. 1 and Fig. 2.
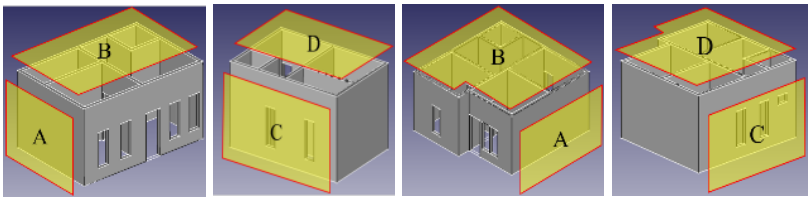

Fig. 1. Force location types for specimens with area $21 \mathrm{~m}^{2}(2$ on the left) and $36 \mathrm{~m}^{2}$ (2 on the right)
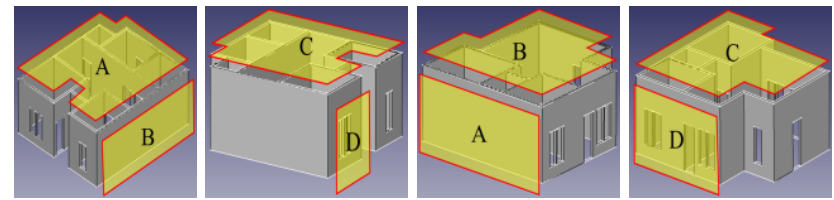

Fig. 2. Force location types for specimens with area $45 \mathrm{~m}^{2}(2$ on the left) and $50 \mathrm{~m}^{2}$ (2 on the right)

Properties inputted in the model are as follows: the brick's density was $2097 \mathrm{~kg} / \mathrm{m}^{3}$, Poisson ratio, v $=0.2$, and Young's modulus of elasticity was $135,000 \mathrm{MPa}$. For the displacement parameter, the structural insecurity limit was chosen to be $0.7 \%$ of the total height. This limit follows the current effective provision of SNI 1726: 2019, Table 20, where the ordinary masonry building with the "I" risk category is $0.7 \%$. Several stress types in masonry material are compressive stress, tensile stress, shear stress, or flexural stress. Based on research by Maidiawati et al. in 2017 [5], the compressive stress value of $3.4 \mathrm{MPa}$ is the stress occurring when the brick structure test object in their study has cracks. In another study by Mavrouli et al. in 2017, the masonry tensile strength was $0.15 \mathrm{MPa}$, and the compressive strength was $1.13 \mathrm{MPa}$ [11]. Another study by Maidiawati et al. in 2011 revealed that the shear stress of the nonstructural masonry brick wall was 0.73 MPa [12]. The smallest stress among the previous study's stress types was adopted to be a conservative limit, which was $0.15 \mathrm{MPa}$. The only stress parameter observed in the LisaFEA program was von Mises stress due to its limitation. However, this stress could represent stress resultant at all three directions and was compared to the set limit.

In determining the number of discretization elements in FEM modeling, convergence analysis was carried out on a test object before it was applied to all test objects to determine the number of effective elements producing a fixed relative displacement at the same load. A volume of 115 to $200 \mathrm{~mm}^{3}$ was applied to the convergence analysis. 3D modeling was performed using FreeCAD software, open-source software, and finite element method analysis was conducted with the help of LisaFEA software. This program only adopted the yield criterion of von-Misses in its analysis. However, it was estimated that the analysis carried out was still in the conservative category and acceptable because the convergence analysis and the limits taken in the linear analysis 
were the maximum stress on the brick. Finally, the displacement and stress were checked for all the cases tested.

Details of the research flow sequentially are presented in

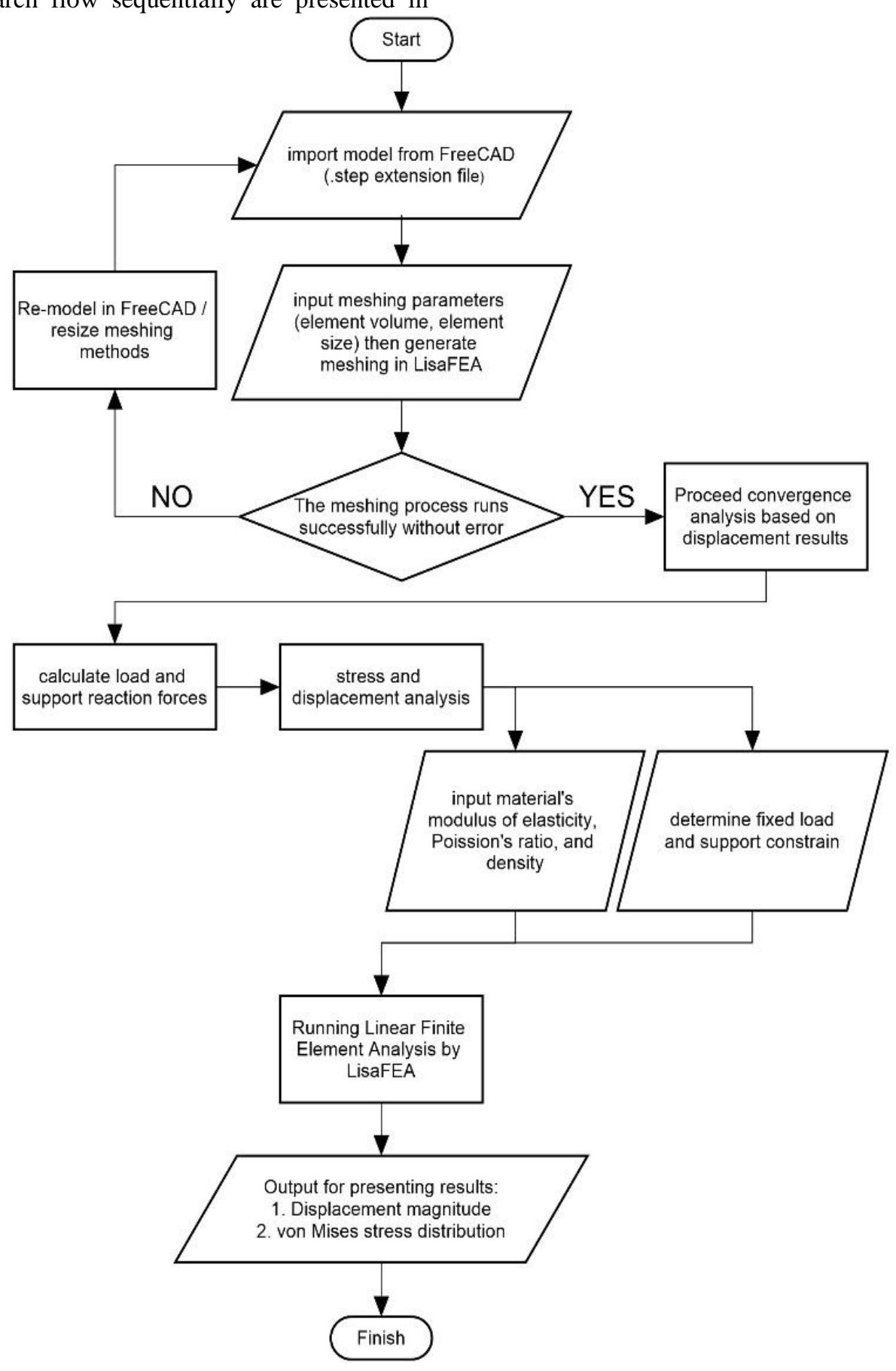

Fig. 3. Research flow in sequential order

\subsection{Implementation of Static Earthquake Load}

The static earthquake load calculation was conducted with the following procedure:

1. The chosen area in this study was Padang, West Sumatera, with the latitude and longitude location of -0.5616 and 100.2141. This location became the subject of this study because there was a big earthquake in 2009 , where many houses, especially masonry buildings, were severely damaged. Soil investigation was not conducted; hence, this paper's site classification was directly picked as SD, a stiff soil profile.

2. Value of spectral response acceleration at a short period, $S_{S}$ and spectral response acceleration at 1 second period, $S_{l}$ from Indonesian Earthquake Hazard Map 2019 were 
retrieved from the program after choosing the location, wherein $\mathrm{Ss}=1.4 \mathrm{~g}$ and $\mathrm{S} 1=0.6 \mathrm{~g}$, as depicted in Fig. 4 .

3. Calculation of crucial spectral acceleration parameters was performed, and the acceleration at the building's natural period was taken to get force by multiplying the selfweight and reduction factor.

4. The fundamental natural period was calculated based on Equation 1, where the parameter $C_{t}$ and $\mathrm{x}$ are empirical parameters based on Table 18 of SNI 1726:2019 for all other structure system and $h_{n}$ is the total height of the structure in meter unit.

$$
T_{a}=C_{t} \cdot \mathrm{h}_{\mathrm{n}}^{\mathrm{x}}
$$

For this case, $T_{a}=0.0488 * 3.5^{0.75}=0.125$ seconds.

5. With $T_{a}=0.125 \mathrm{~s}$, the spectral acceleration design, $S_{a}$, was retrieved by reading the response spectrum graph as depicted in Fig. 5, which equals to $0.857 \mathrm{~g}$ or $8.41 \mathrm{~m} / \mathrm{s}^{2}$, with the modification response coefficient for ordinary masonry of 1.5 .

27 Peta Gempa dan Respons Spektra 2019, (C) ESRC-PUSGEN-PUSKIM PUPR, 2019-2020

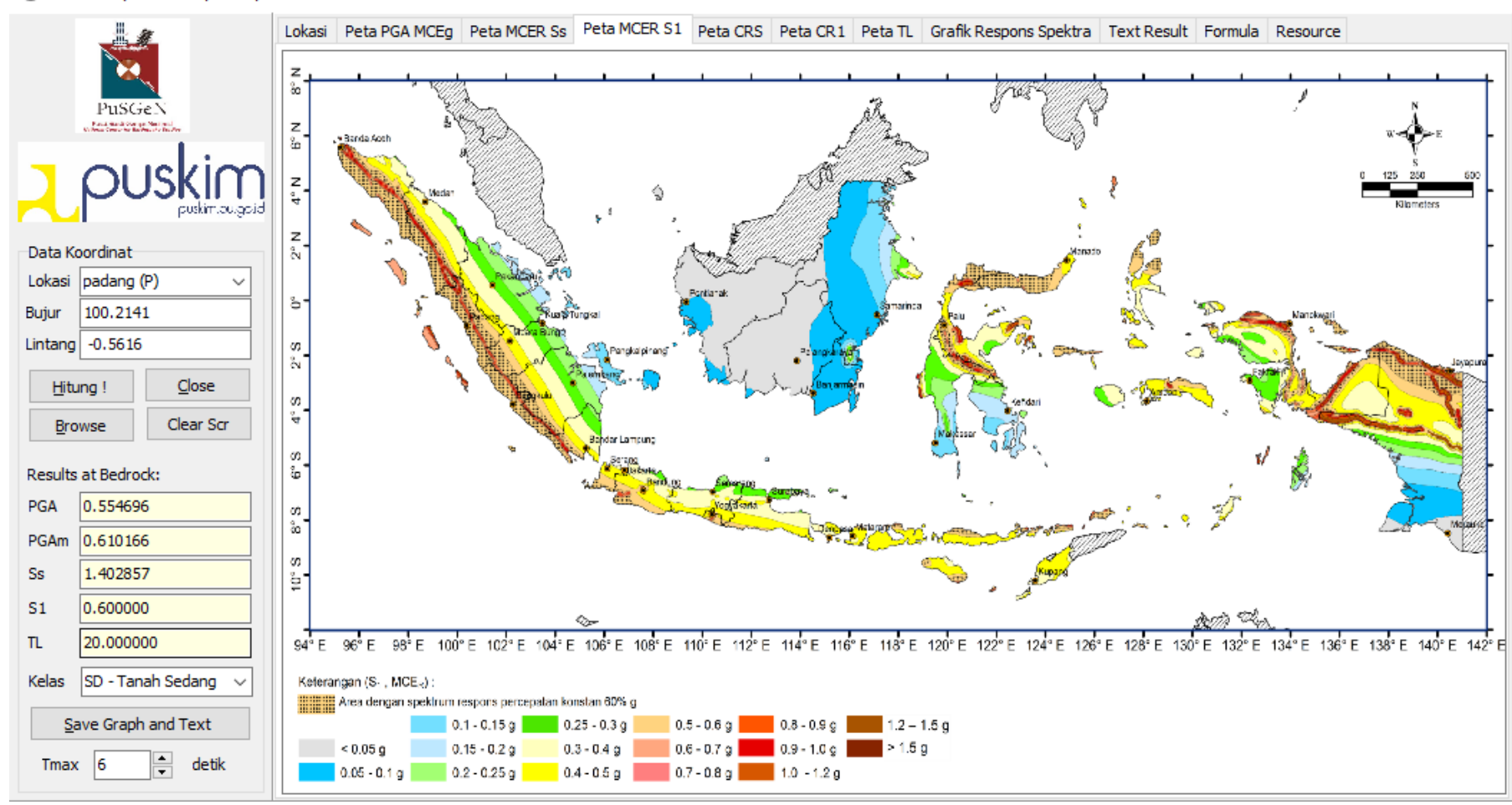

Fig. 4. Preview of Indonesian Earthquake Hazard Map 2019-2020 [2]

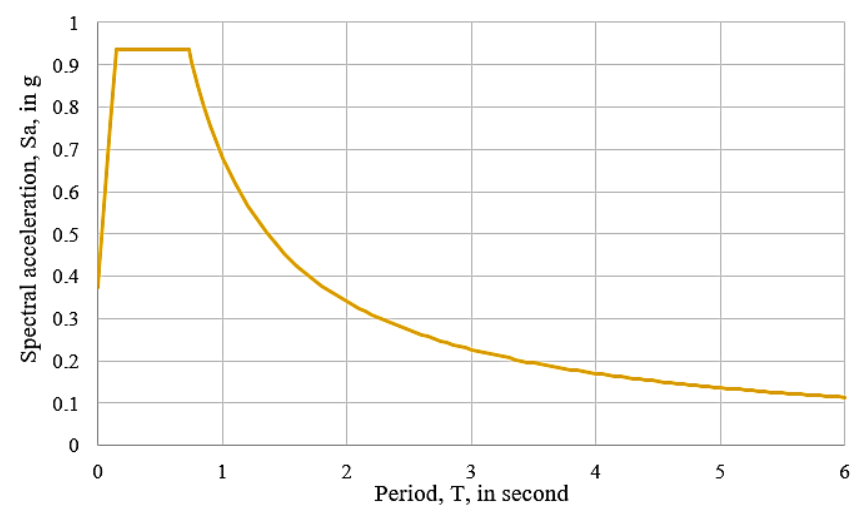

Fig. 5. Response spectrum graph for this study

6. The masonry self-weight was calculated using the total volume in the model and a masonry density of 2,097 $\mathrm{kg} / \mathrm{m}^{3}$. In this case, for a self-weight building specimen with a total area of $21 \mathrm{~m}^{2}$, the volume total was $13.85 \mathrm{~m}^{3}$, and the weight was $29,037.53 \mathrm{~kg}$.
7. Earthquake static force was calculated with the following Equation 2:

$$
\mathrm{F}=\mathrm{m} \cdot S_{a} \cdot \frac{\mathrm{I}}{\mathrm{R}}
$$

where $\mathrm{m}$ is weight in $\mathrm{kg}, S_{a}$ is earthquake acceleration in $\mathrm{m} / \mathrm{s}^{2}$, I parameter is an essential factor, taken as 1 because the building function is housing, and $\mathrm{R}$ means modification response coefficient, chosen as 1.5 .

8. The distribution and position of earthquake load were varied in four ways, A, B, C, and D. Each letter symbolizes the distribution direction and location; for example, Fig. 6(a) is the way the earthquake load applied for case A in Fig. 1, where all the earthquake force is distributed in one side masonry wall. Meanwhile, case B in Fig. 6(b) is distributed in the top surface area. The forces are depicted as green arrows at each affected elements' surface. This distribution method was the closest way to implement the static horizontal load to conduct linear FEM in LisaFEA due to the program limitation. 

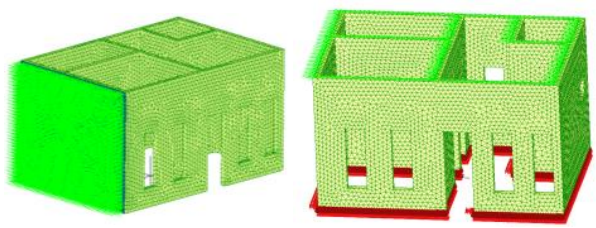

(a)

(b)

Fig. 6. Static earthquake force implementation method in LisaFEA

\section{RESULTS AND DISCUSSION}

Convergence analysis was performed by varying the volume of 18 discretization elements from $115-200 \mathrm{~mm}^{3}$ with an increase in the volume variation of $5 \mathrm{~mm}^{3}$ for each element. By inputting the element size, the LisaFEA program automatically divided the structure by referring to the maximum element volume predetermined. Fig. 7 indicates that the element volume of $125 \mathrm{~mm}^{3}$ with the number of elements 40,615 starts to produce a stable displacement until the element's volume reaches $115 \mathrm{~mm}^{3}$ with the number of elements of $48,150 \mathrm{~mm}^{3}$ with the displacement value of 1.247 $\mathrm{mm}$. Therefore, the element volume of $120 \mathrm{~mm}^{3}$ was selected as input to the LisaFEA in the finite element method analysis from the convergence analysis carried out.

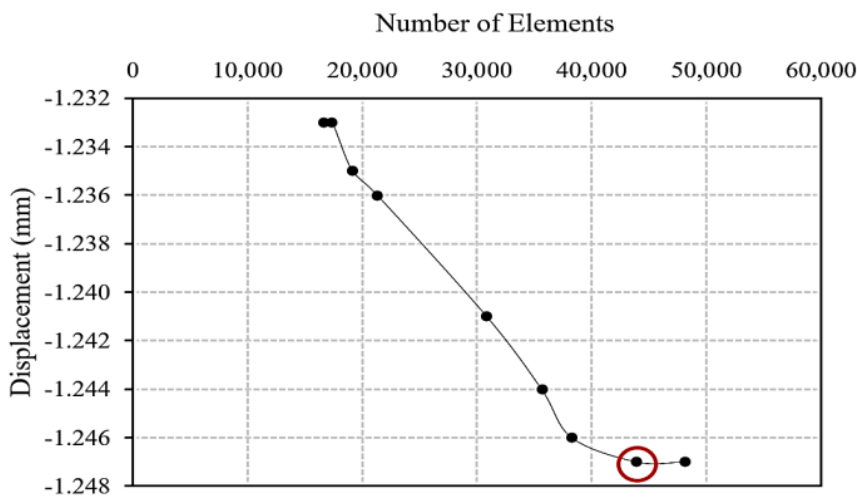

Fig. 7. Convergence analysis results by varying the number of elements

The convergence analysis unveiled that the displacement differences between the small volume size of finite element and the largest size trials have very slight differences, about $1.5 \%$. Therefore, the convergence analysis is not necessarily needed to be conducted further. Nonetheless, all analyses adopted an element size of $115 \mathrm{~mm}^{3}$.

The finite element analysis using LisaFEA software revealed that the response displacement and stress values were obtained for each element when applying static lateral force. From all these results, the maximum absolute values of displacement and stress were read and recorded. These values were then compared with the predetermined limits, namely $24.5 \mathrm{~mm}$ for displacement and $0.15 \mathrm{MPa}$ for comparing with von Mises stress results. A summary of the results for all types of area and loading direction is presented in Table I.
Table I. Recapitulation Results for All Specimens

\begin{tabular}{|c|c|c|c|c|c|}
\hline $\begin{array}{c}\text { Specime } \\
\text { ns (unit } \\
\text { area of } \\
\mathbf{m}^{2} \text { ) }\end{array}$ & $\begin{array}{l}\text { Force } \\
\text { Directi } \\
\text { on }\end{array}$ & $\begin{array}{c}\text { Observed } \\
\text { absolute } \\
\text { max. } \\
\text { displacemen } \\
\text { t (mm) } \\
\end{array}$ & 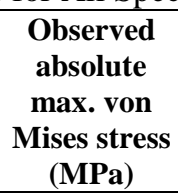 & $\begin{array}{c}\mathbf{P} \\
\mathbf{a}\end{array}$ & $\underset{\mathbf{b}}{\mathbf{Q}}$ \\
\hline \multirow{4}{*}{21} & X_A & 1.564 & 3.19 & Y & $\mathrm{N}$ \\
\hline & X_B & 1.247 & 3.19 & Y & $\mathrm{N}$ \\
\hline & Y_C & 1.799 & 3.89 & Y & $\mathrm{N}$ \\
\hline & Y_D & 1.697 & 4 & $\mathrm{Y}$ & $\mathrm{N}$ \\
\hline \multirow{4}{*}{36} & X_A & 1.675 & 3.9 & Y & $\mathrm{N}$ \\
\hline & X_B & 1.24 & 3.4 & Y & $\mathrm{N}$ \\
\hline & Y_C & 2.292 & 7.44 & Y & $\mathrm{N}$ \\
\hline & Y_D & 1.617 & 3.19 & Y & $\mathrm{N}$ \\
\hline \multirow{4}{*}{45} & X_A & 1.649 & 4.1 & Y & $\mathrm{N}$ \\
\hline & X_B & 2.616 & 4.81 & Y & $\mathrm{N}$ \\
\hline & Y_C & 1.818 & 3.71 & $\mathrm{Y}$ & $\mathrm{N}$ \\
\hline & Y_D & 8.132 & 19.3 & $\mathrm{Y}$ & $\mathrm{N}$ \\
\hline \multirow{4}{*}{50} & X_A & 3.738 & 4.44 & $\mathrm{Y}$ & $\mathrm{N}$ \\
\hline & X_B & 5.552 & 4.86 & Y & $\mathrm{N}$ \\
\hline & Y_C & 3.738 & 4.44 & $\mathrm{Y}$ & $\mathrm{N}$ \\
\hline & Y_D & 5.552 & 4.86 & Y & $\mathrm{N}$ \\
\hline \multicolumn{6}{|c|}{$\begin{array}{l}\text { Displacement limit }(24.5 \mathrm{~mm}) \text {, Y means displacement results in less than } \\
24.5 \mathrm{~mm}, \mathrm{~N} \text { means large }\end{array}$} \\
\hline
\end{tabular}

Table I implies that all observed absolute maximum displacements are less than allowable displacement, while several specimens show that the absolute maximum stress exceeds the predetermined limit, namely the specimen $36 \mathrm{~m}^{2}$ in the $\mathrm{Y}$ direction for the type $\mathrm{C}$ loading location, specimen 45 $\mathrm{m}^{2}$ in the $\mathrm{X}$ direction for the type $\mathrm{B}$ loading location and the $\mathrm{Y}$ direction for the $\mathrm{D}$ loading location, and all type $50 \mathrm{~m}^{2}$ directions. It may be due to the complexity of the relationship between the in-plane and out-of-plane walls, which in the specimens with a larger area, is relatively more. Besides, because the structure is homogeneous, and there is no reinforcement in reinforced concrete columns and beams and with an increasing wall area, the stresses are getting bigger. Furthermore, the application of lateral loads to the outside of the plane walls also increases the stress. For example, Fig. 8 is the stress distribution in masonry due to lateral static loading. The observations revealed that the greatest stress occurred and was concentrated at the intersection of the perpendicular walls, namely the in-plane and out-of-plane walls.

The modeling in this study was imperfect due to many limitations assumed based on previous studies. For better results, modeling in future research is suggested to consider the whole specimen, such as applying more detailed failure criteria, defining mortar materials, bricks, and their relationships separately, as well as dynamic loading located at the base building. 


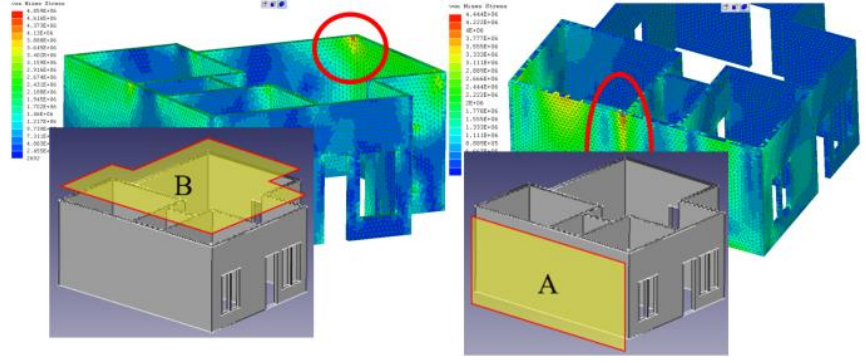

Fig. 8. Stress distribution occurred in the $50 \mathrm{~m}^{2}$ specimen in the $\mathrm{X}$ direction of loading $\mathrm{A}$ (left) and $\mathrm{B}$ (right)

\section{CONCLUSIONS}

Simple masonry house structures had been modeled in three dimensions. Response parameters due to lateral static loads such as displacement and stress for four building types with typical areas were recapitulated. The analysis results disclosed that in linear modeling without considering cracks and ruptures, the displacement value for all specimens was in accordance with the SNI 1726: 2019, 0.7\% of the building's interstorey height. However, all of the von Mises stresses specimens did not fit the prescribed limit. The observation revealed that the stress maximum was concentrated at the perpendicular meeting point between in-plane and out-ofplane masonry walls. Since all stresses did not conform to the limit, it would be unsafe to use only masonry material for houses without reinforcement, such as beam-column frame structures. Further studies should be conducted where the model includes a framework for determining the improved displacement stress responses and incorporates other necessary parameters such as the crack limit. It is expected that these findings will be useful for further research and concerned stakeholders.

\section{REFERENCES}

[1] U.N. Department of Economic and Social Affairs, World Population Prospects 2019 Highlights. New York, 2019.

[2] Badan Standardisasi Nasional, "SNI 1726:2019 Tata cara perencanaan ketahanan gempa untuk struktur bangunan gedung dan nongedung [Design Method of Earthquake Resilience for Structural and Nn Structural Building]," Jakarta, 2019. (In Indonesian Language)

[3] H. Prayuda, E. A. Setyawan, and F. Saleh, "Analysis Physical and mechanical attributes of masonry in Yogyakarta," Jurnal Riset Rekayasa Sipil, 2018, vol. 1, no. 2, p. 94,. (In Indonesian Language)

[4] S. P. Narayanan and M. Sirajuddin, "Properties of Brick Masonry for FE modeling," American Journal of Engineering Research, 2013, no. 1, pp. 2320-847.

[5] M. Maidiawati, J. Tanjung, and H. Medriosa, "The Effect of Brick Wall with Hole to the Lateral Resistance in Reinforce Concrete" [Pengaruh Dinding Bata dengan Bukaan (Lobang) terhadap Ketahanan Lateral Struktur Rangka Beton Bertulang], Jurnal Teknik Sipil, 2017, vol. 24, no. 2, pp. 145-152. (In Indonesian Language)

[6] G. Milani, P. Lourenço, and A. Tralli, "3D homogenized limit analysis of masonry buildings under horizontal loads," Engineering Structures, 2007, vol. 29, no. 11, pp. 3134-3148.

[7] D. Vamvatsikos and S. J. Pantazopoulou, "Simplified mechanical model to estimate the seismic vulnerability of heritage unreinforced masonry buildings," Journal of Earthquake Engineering, 2016, vol. 20, no. 2, pp. 298 325.

[8] T. I. Maulana, B. Soebandono, B. S. Jagad, and H. Prayuda, "Stress and deformation analysis of tapered cantilever castellated beam using numerical method," IOP Conference Series: Materials Science and Engineering, 2018, vol. 352, no. 1 .

[9] T. I. Maulana, H. Prayuda, B. Soebandono, M. Dwi Cahyati, and E. Hanifatu Zahra, "Numerical analysis on stress and displacement of tapered cantilever castellated steel beam with circular openings," MATEC Web of Conferences. 2018, vol. 195.

[10]R. Faizah, "Comparison Study on Static and Dynamic Earthquake Load History in High Rise Building in Yogyakarta " [Studi Perbandingan Pembebanan Gempa Statik Ekuivalen dan Dinamik Time History pada Gedung Bertingkat di Yogyakarta] Semesta Teknika. 2015. vol. 18, no. 2, pp. 190-199. (In Indonesian Language)

[11]O. Mavrouli, P.G. Giannopoulos, J.M. Carbonell, \& C. Syrmakezis. "Damage analysis of masonry structures subjected to rockfalls," Landslides, 2017, vol. 14, no. 3, pp. 891-904.

[12]M. Maidiawati, Y. Sanada, D. Konishi, and J. Tanjung, "Seismic performance of nonstructural brick walls used in Indonesian R/C buildings," Journal of Asian Architecture and Building Engineering, 2011, vol. 10 no. 1, pp. 203210 